\title{
Marx's Centenary (1918) in the Light of the Media and Socialist Thought
}

\section{Christian Fuchs}

University of Westminster, London, UK, c.fuchs@westminster.ac.uk, @fuchschristian, http://fuchs.uti.at, christian.fuchs@triple-c.at

\begin{abstract}
This article takes a historical view on Marx's anniversary: It analyses how Marx's centenary (5 May 1918) was reflected in the media and socialist thought. 1918 not just marked Marx's 100th anniversary but was also the year in which the First World War ended. It was the year that saw the immediate aftermath of the Russian Revolution and the start of the Russian Civil War, the end of the Austro-Hungarian Empire; the formation of the Weimar Republic, Austria's First Republic, the Czech Republic, the Hungarian Republic, the Second Polish Republic; the founding of the Communist Party of Germany (KPD), and the independence of Iceland from Denmark. The cultural forms, in which Marx's centenary was reflected in 1918, included press articles, essays, speeches, rallies, demonstrations, music, and banners. The communists as well as left-wing socialists of the day saw themselves in the tradition of Marx, whereas revisionist social democrats based their politics on a criticism or revised reading of Marx. This difference resulted in different readings of Marx.
\end{abstract}

Keywords: Karl Marx, centenary, 5 May 1918, bicentenary, 200th anniversary, 5 May 2018, 1818

\section{Introduction}

We can take Marx's bicentenary as an occasion for having a look at some aspects of his centenary in 1918. 1918 marked not just Marx's 100th anniversary but also the year in which the First World War ended. It was the year that saw the immediate aftermath of the Russian Revolution and the start of the Russian Civil War, the end of the AustroHungarian Empire; the formation of the Weimar Republic, Austria's First Republic, the Czech Republic, the Hungarian Republic, the Second Polish Republic; the founding of the Communist Party of Germany (KPD), and the independence of Iceland from Denmark.

The communists as well as left-wing socialists of the day saw themselves in the tradition of Marx, whereas revisionist social democrats based their politics on a criticism or revised reading of Marx. This difference resulted, as we will see, in different readings of Marx.

\section{Communists and Left Socialists on Marx's Centenary}

After the Social Democratic Party of Germany (SPD) had in August 1914 voted for war credits that had enabled the mobilisation of the German army in the First World War, Rosa Luxemburg, Hermann Duncker, Hugo Eberlein, Julian Marchlewski, Franz Mehring, Ernst Meyer, Wilhelm Pieck and Karl Liebknecht founded the Gruppe Internationale (Group International) that in 1916 became the Spartacus League. Spartacus in 1917 became part of the Independent Social Democratic Party of Germany (USPD), a split-off from the SPD, and turned at the end of 1918 into the Communist Party of Germany (KPD). 


\section{Rosa Luxemburg and Franz Mehring}

Rosa Luxemburg was imprisoned from 18 February 1915 until 9 November 1916. She was jailed for two speeches in which she had called for conscientious objection. After she had served the sentence, she was not immediately released because she was considered a security threat. At the time when Marx's centenary was celebrated, Rosa Luxemburg was a political prisoner. Writing was, as one can imagine, difficult in prison, but Luxemburg managed to secretly write the Junius Pamphlet: The Crisis in the German Social Democracy (1916) in 1915. The pamphlet was published anonymously in 1916 and distributed illegally in Germany.

Luxemburg had written the chapter on Capital Volumes 2 and 3 for Franz Mehring's Marx biography that was published in May 1918 (Mehring 2003/1936). In a letter to Mehring, Luxemburg $(2011,458)$ wrote on December 30, 2017: "How fine that your Marx [...] will soon appear, which is truly a gleam of light in these sorry times. I hope the book will be a stimulus and an encouragement for a great many people and at the same time a nostalgic reminder of that lovely time when one did not yet have to be ashamed to call oneself a German Social Democrat". Convinced by the book's excellence, she nonetheless had doubts about its effectiveness, as she wrote in a letter to Clara Zetkin on 29 June 1918: "I find it magnificent and promise myself it will have a powerful impact on the masses. If only they will read it!" (Ibid., 463).

In her chapter in Mehring's book, Luxemburg points out that the achievement of Capital is that "Marx showed for the first time how profit originated and how it flowed into the pockets of the capitalists. He did so on the basis of two decisive economic facts: first, that the mass of the workers consists of proletarians who are compelled to sell their labour-power as a commodity in order to exist, and secondly that this commodity labour-power possesses such a high degree of productivity in our own day that it is able to produce in a certain time a much greater product than is necessary for its own maintenance in that time" (Rosa Luxemburg, quoted in Mehring 2003/1936, 372). The second volume of Capital investigates how a whole is developed from the innumerable deviating movements of individual capital" (Ibid., 375). "In the first volume he [Marx] deals with the production of capital and lays bare the secret of profit-making. In the second volume he describes the movement of capital between the factory and the market, between the production and consumption of society. And in the third volume he deals with the distribution of the profit amongst the capitalist class as a whole. [...] In the first volume we are in the factory, in the deep social pit of labour where we can trace the source of capitalist wealth. In the second and third volumes we are on the surface, on the official stage of society. Department stores, banks, the stock exchanges, finance and the troubles of the 'needy' agriculturalists take up the foreground" (Rosa Luxemburg, quoted in Mehring 2003/1936, 376, 377).

"The investigations which Marx pursues in the second and third volumes of Capital offer a thorough insight into the nature of crises" (Rosa Luxemburg, quoted in Mehring 2003/1936, 378). One hundred years later after this analysis of Luxemburg was published in the year of Marx's centenary, capitalism has gone through several more crisis stages, of which the latest began in 2008 and created a great recession. New authoritarianisms and new nationalisms emerged in the context of this crisis. Marx and Luxemburg remind us that the capitalist system is inherently crisis-ridden and that crises can within that system at a maximum be suspended temporarily and sooner or later always come back in new forms.

So Franz Mehring was author of one of the first biographies of Karl Marx (Mehring 2003/1936) and a comrade of Rosa Luxemburg, Karl Liebknecht and Clara Zetkin. Mehring was one of the people who together with Luxemburg founded the Spartacus 
League that became the Communist Party of Germany (KPD). Mehring published on the occasion of Marx's centenary an article in Leipziger Volkszeitung on 4 May 1918. He wrote: "Karl Marx's centenary directs our view from a gruesome presence to a brighter future just like a bright sunbeam that breaks through dark and apparently impenetrable cloud layers [...] Tireless and restless critique [...] was his true weapon. [...] To continue working based on the indestructible foundations that he laid is the most worthy homage we can offer to him on his one hundredth birthday" (Mehring 1918, 11, 15).

\section{Max Adler}

The Austro-Marxist philosopher and politician Max Adler was a left socialist who was part of the left wing of Austrian social democracy. In May 1918, he published the pamphlet Die sozialistische Idee der Befreiung bei Karl Marx (Karl Marx's Socialist Idea of Liberation). He wrote: "The poet's words 'For I have been a man, and that Means I have been a combatant ${ }^{2}$ has for the proletariat through Karl Marx gained the deeper historical meaning that the proletariat only as struggling class reaches humanity. The World War's inhumanity has given the proletariat a terrible object lesson of this circumstance. [...] It is only in this context that Marx will again become teacher and leader. The true celebration of his centenary consists not in mere commemoration of his works and teachings, but in keeping alive his revolutionary spirit”3 (Adler 1918, 489).

\section{Antonio Gramsci}

Italy at the time of Marx's centenary fought as part of the Allied Powers in the First World War. Antonio Gramsci was at that time a member of the Italian Socialist Party (PSI), lived in Turin, where he was PSI secretary, and was the editor of the Socialist Party's weekly II Grido del Popolo (The People's Cry). On 4 May 1918, Gramsci (1918) published the essay "II nostro Marx" ("Our Marx") on the occasion of Marx's centenary.

In this article, Gramsci writes that Marx's "only categorical imperative" is, "Workers of the world, unite!' The duty of organizing, the propagation of the duty to organize and associate, should therefore be what distinguishes Marxists from non-Marxists" (Gramsci 1918, 36). Organisation and political action as such are not necessarily progressive. Also fascists organise in political groups and movements that act politically in public. So what Gramsci leaves out is that for Marx not political practice, but praxis - socialist political practice - is decisive.

Gramsci stresses that for Marx, ideas are not immaterial or fictitious, but grounded

${ }^{1}$ Translated from German. German original: „Wie ein heller Sonnenstrahl, der durch düstere und scheinbar undurchdringliche Wolkenschichten bricht, so lenkt heute der hundertste Geburtstag von Karl Marx unseren Blick aus einer grauenvollen Gegenwart in eine hellere Zukunft [...] die rast- und ruhelose Kritik [...] ist seine wirkliche Waffe gewesen [...] So fortzuarbeiten auf den unzerstörbaren Grundlagen, die er gelegt hat, ist die würdigste Huldigung, die wir [...] [ihm] an seinem hundertsten Geburtstage darbringen können“.

${ }^{2}$ Goethe $(1914,180)$

${ }^{3}$ German original: „Das Dichterwort ,Denn ich bin ein Mensch gewesen. Und das heißt ein Kämpfer sein' hat für das Proletariat durch Karl Marx die tiefere entwicklungsgeschichtliche Bedeutung erhalten, daß das Proletariat erst als Klassenkämpfer überhaupt zum Menschentum gelangt. Die Unmenschlichkeit des Weltkrieges hat dem Proletariat drüber einen furchtbaren Anschauungsunterricht erteilt. [...] Hier nun erst wird Marx wieder Lehrer und Führer werden. Die wirkliche Jahrhundertfeier für ihn besteht nicht in einem bloßen Gedenken seines Schaffens und Lehrens, sondern in der Lebendigerhaltung seines revolutionären Geistes". 
in the economy: "With Marx, history continues to be the domain of ideas, of spirit, of the conscious activity of single or associated individuals. But ideas, spirit, take on substance, lose their arbitrariness, they are no longer fictitious religious or sociological abstractions. Their substance is in the economy, in practical activity, in the systems and relations of production and exchange" (Gramsci 1918, 37).

Knowledge labour has today become a key feature of capitalist society. The intersection of ideas and labour in the contemporary economy strengthens Gramsci's interpretation of Marx, in which there is no strict base/superstructure separation and ideas operate within the economy.

Marx "is a monolithic bloc of knowing and thinking humanity [...] who constructs iron syllogisms which encircle reality in its essence and dominate it, which penetrate people's minds, which bring the sedimentations of prejudice and fixed ideas crumbling down and strengthen the moral character" (Ibid., 39). Today, we see the rise of new nationalisms and authoritarianisms that use prejudices for trying to divide humanity and distract attention from class conflicts and class structures. Marx's humanism and method of ideology critique are today of key importance for challenging these developments.

\section{Eugene V. Debs}

Eugene V. Debs was one of the founders of the International Workers of the World (IWW) and of the Socialist Party of America and its predecessor parties. The Socialist Party opposed the USA's entry into the First World War, which resulted in the First Red Scare. Debs on 4 May 1918, published an article that commemorated Marx for struggling "to destroy despotism in all its form" and to emancipate humankind "from the slavery of the ages". In November 1918, Debs was sentenced to ten years in prison for sedition. He was released at the end of 1921. Debs and his socialist contemporaries struggled against the authoritarian tendencies of their time. He considered Marx's works and life as a guiding light for the struggle against authoritarianism. One hundred years later, new authoritarian dangers have emerged. Also today, Marx reminds is of the need "to destroy despotism".

In Russia, the Soviet government signed the Peace Treaty of Brest-Litovsk with Germany, Austria-Hungary, Bulgaria and the Ottoman Empire on 3 May 1918. Seven members of the Central Committee of the Communist Party of the Soviet Union had voted in favour of such a treaty, four against, four members abstained. The Central Soviet Executive passed the resolution with 112 votes in favour, 84 oppositional votes and 24 abstentions. Not everyone agreed with this decision. In April 1918, a group of Left Communists led by Nikolai Bukharin and Karl Radek published "Theses on the Current Situation" (Left Communists 1918), in which they argued that the Peace Treaty was a "capitulation to international imperialism" and had "negative effect on the spiritual and psychological development of the international revolution" (Ibid.).

\section{Lenin}

On the day of Marx's centenary, Lenin (1918) wrote a response to the Left Communists under the title "Left-Wing" Childishness and the Petty-Bourgeois Mentality. Lenin disagreed with the Left Communists' hasty call for world revolution: "For, until the world socialist revolution breaks out, until it embraces several countries and is strong enough to overcome international imperialism, it is the direct duty of the socialists who have conquered in one country (especially a backward one) not to accept battle against the 
giants of imperialism. Their duty is to try to avoid battle, to wait until the conflicts between the imperialists weaken them even more, and bring the revolution in other countries even nearer" (Ibid., 327).

Lenin refers to Marx in order to stress that "Marx was profoundly right when he taught the workers the importance of preserving the organisation of large-scale production, precisely for the purpose of facilitating the transition to socialism" (Ibid., 345). "Socialism is inconceivable without large-scale capitalist engineering based on the latest discoveries of modern science" (Ibid., 339).

Lenin is certainly right in stressing with Marx that post-capitalism needs to use modern technologies for establishing a post-scarcity society so that emancipation from toil and true freedom become possible. But the problem was that Lenin on the occasion of Marx's centenary did not read Marx thoroughly enough. He adopted an uncritical celebration and uptake of Taylorism, including its de-humanising aspects such as repetitive, monotonous labour. Soviet labour was not less alienated than labour in Western capitalist societies.

The point is that socialist technology needs to be a sublation of capitalist technology, i.e. a simultaneous preservation of the best elements, elimination of negative design features, and the development of new qualities. Marx and Engels spoke in this context already in The German Ideology of the appropriation of technology. They make clear that appropriation means a transformation that is at the same time revolution/overthrow/ceasing-to-be and development/coming-to-be: "The appropriation of a totality of instruments of production is, for this very reason, the development of a totality of capacities in the individuals themselves. [...] This appropriation is further determined by the manner in which it must be effected. It can only be effected through a union, which by the character of the proletariat itself can again only be a universal one, and through a revolution, in which, on the one hand, the power of the earlier mode of production and intercourse and social organisation is overthrown, and, on the other hand, there develops the universal character and the energy of the proletariat, without which the revolution cannot be accomplished; and in which, further, the proletariat rids itself of everything that still clings to it from its previous position in society. Only at this stage does self-activity coincide with material life, which corresponds to the development of individuals into complete individuals and the casting-off of all natural limitations. The transformation of labour into self-activity corresponds to the transformation of the earlier limited intercourse into the intercourse of individuals as such. With the appropriation of the total productive forces through united individuals, private property comes to an end" (Marx and Engels 1845/46, 87-88).

Marx further developed the idea of appropriation as dialectical becoming in the Grundrisse. Only a dialectic of old and new elements of technology makes possible that what Hardt and Negri (2017) based on Marx call the appropriation of fixed capital results in "disposable time" ceasing to have "an antithetical existence" (Marx 1857/58, 708), "the powers of social production" - including the "general intellect" - becoming "the real life process" (Ibid., 706), the "free development of individualities" that "then corresponds to the artistic, scientific etc. development of the individuals in the time set free" (Ibid.). Social production means for Marx that human subjects exist "in mutual relationships, which they equally reproduce and produce anew" in a "constant process of their own movement, in which they even renew themselves even as they renew the world of wealth they create" (Ibid., 712). In a society of the commons, humans produce truly in an open, dynamic process and so do not stop developing technologies, but give new qualities to old technologies and create entirely new technologies. 
Today, in the age of digital capitalism, we can not simply in a Leninist manner appropriate capitalist digital technologies by stopping at socialising the ownership of Facebook, Google, Amazon, Apple, etc. One also needs qualitative changes of digital technologies. So for example turning Facebook into a co-operative ownership does not automatically change its individualistic structures that enable the accumulation of online reputation. Socialisation and co-operation has to include a qualitative transformation of Facebook's platform design structures and policies.

\section{Socialist Party of Great Britain}

Jack Fitzgerald was in 1904 one of the founders of the Socialist Party of Great Britain. He was the editor of the Party's journal Socialist Standard, where he in May 1918 published an article on "The Centenary of Marx". In it, Fitzgerald (1918) wrote: "Of Capital it is no exaggeration to say that no work ever written on economics has attracted so much attention and attempted criticism. Every professor of political economy and every petty journalist feels bound to criticise, without having troubled to read, Marx's unanswerable exposure of the present system. The two great features of Capital are the solving of the riddle of Value and the demonstration of the appropriation of Surplus-Value". 2017 was the 150th anniversary of the publication of Capital Volume 1's first edition. Fitzgerald's judgment certainly also holds true one hundred years later: Marx and Capital are heavily discussed, but too many people make claims about both without having thoroughly engaged with them.

\section{Reformist and Revisionist Social Democracy on Marx's Centenary}

Arbeiter-Zeitung, the daily newspaper of the Austrian social democrats, wrote on the day of Marx's centenary: "And yet, we do not celebrate a dead person today when we commemorate Marx. His name is today still a battle cry as good as it was then when the thirty-year old threw his Communist Manifesto into the world. He is still today awakening sleeping souls and is today still collecting, uniting and spearheading the proletarians of all countries" ${ }^{4}$ (Arbeiter-Zeitung 1918, 1).

Other than Luxemburg, Liebknecht and Zetkin, Karl Kautsky did not clearly oppose the German Social Democrats' support of war credits. From 1916 onwards, Kautsky opposed the First World War, which led in 1917 to the creation of the Independent Social Democratic Party of Germany (USPD). Kautsky's criticism of Marxists' nationalist support of the First World War on the occasion of Marx's centenary was at the same time also a piece of self-criticism: "The celebration of the 100th birthday of our master will be the first act since the outbreak of the World War for which the proletarians of all countries unite"; Marxism was "partly dispersed into national parties that abet national hatred and the national lust for conquest of their governments and dominant classes" ${ }^{5}$ (Kautsky 1918, 1). Kautsky reminded the readers that Marx had opposed

${ }^{4}$ German original: „Und doch, nicht einen Toten feiern wir heute, wenn wir Marxens gedenken. Sein Name ist heute noch ein Kampfruf - so gut wie damals, als der der Dreißigjährige sein Kommunistisches Manifest in die Welt schleuderte. Er ist heute noch der Wecker schlafender Seelen, heute noch Sammler und Einiger und Vorkämpfer der Proletarier aller Länder".

5 „Die Feier des hundertsten Geburtstages unseres Meisters wird seit Ausbruch des Weltkrieges die erste Handlung sein, zu der sich wieder die Proletarier aller Länder vereinigen“. Marxismus ist „zum Teil in nationale Parteien zersprengt, die nationalem Haß und nationaler Eroberungsgier ihrer Regierungen und herrschenden Klassen Vorschub leisten“. 
Realpolitik and had favoured revolutionary politics. For Marx, the proletariat was revolutionary and therefore "constantly driven by a wide goal that transcends existing soci-

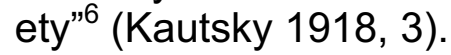

Joseph Schumpeter was in 1918 professor of political economy at the University of Graz and worked in a commission of the German government that prepared the nationalisation of some parts of German industry. He was not a follower of Marx's theory, but in a newspaper article published on the day of Marx's centenary he praised Marx as political economist and sociologist. "What is unique about him is that he was the inseparable penetration of researcher and fighter, that he only conducted research in order to give direction to struggles and only struggled in order put the results of his research into action"7 (Schumpeter 1918, 3).

Vorwärts has since 1876 been the newspaper of the Social Democratic Party of Germany. Wilhelm Liebknecht was one of the founding editors. Die Neue Zeit was the Party's theoretical journal and existed from 1883 until 1923. At the time of Marx's centenary, German social democracy was split into the Spartacus League that later in the same year became the Communist Party of Germany, the centrist Independent Social Democratic Party of Germany (USPD) and the rightist Social Democratic Party of Germany (SPD). Interestingly, Die Neue Zeit and Vorwärts formulated different positions on how to think about Marx's centenary.

Heinrich Cunow, who in the years from 1917 until 1932 edited Die Neue Zeit - the academic publication of German social democracy -, wrote about Marx's 100th birthday: "Marx protrudes among the geniuses whose names are engraved into the plaques of honour and who lived during the nineteenth century's second half as conquering the realm of the intellectual history. [...] His work has not come to an end. The spirit of this man, whose mortal remains have now been covered by Highgate Cemetery's lawn since more than 35 years, still exerts vital power. [...] Marx's enormous influence on theoretical-political economy, the interpretation of history and proletarian struggles in almost all European states proves well enough his importance" (Die Neue Zeit 1918, 97-98).

On the day of Marx's centenary, Vorwärts reported on its title page that Marxists were deeply split: In Russia, the Bolsheviks and Mensheviks would kill each other. In France, the celebrations planned by Marx's grandson Jean-Laurent-Frederick Longuet would have been circumvented by war-supporting socialists. In Germany, "the split of the Party is an accomplished fact" (Vorwärts 1918, 1). "In Germany, the Marx celebrations must limit themselves to appraisals of the master in the press and festivities

${ }^{6}$ "ist stets getrieben durch ein weites, über die bestehende Gesellschaft hinausgehendes Ziel“.

7 "Und das Einzigartige an inm ist, daß der Forscher und der Kämpfer in inm einander untrennbar durchdringen, daß er nur forschte, um seinem Kämpfen die Richtung zu geben und nur kämpfte, um das Resultat seiner Forschung durch die Tat zu vertreten".

${ }^{8}$ German original: „Als ein Welteroberer auf dem Gebiet der Geistesgeschichte ragt Marx unter den Geistesgrößen der zweiten Hälfte des neunzehnten Jahrhunderts hervor, die auf die Steintafeln des Ruhmes ihren Namen eingegraben haben. [...] sein Wirken ist nicht beendet. Noch immer geht von dem Geist dieses Mannes, dessen sterbliche Hülle nun schon seit mehr als 35 Jahren der Rasen des Friedhofs von Highgate deckt, eine lebendige Kraft aus. [...] Der enorme Einfluß den Marx auf die Entwicklung der theoretisch-politischen Ökonomie wie auf die Geschichtsbetrachtung und die proletarischen Parteikämpfe in fast allen europäischen Staaten gehabt hat, beweist zur Genüge die Bedeutung des Mannes“.

9 „ist die Parteispaltung vollendete Tatsache“ 
in closed circles"10 (Vorwärts 1918, 1). The article on the one hand justifies rightist German Social Democrats' support of the First World War. On the other hand, it is a deeply pessimist piece that expresses sorrow over the bad status of Social Democracy and its 1917 split into two parties (the USDP and the SPD). Marx was in the article seen as someone who did not matter in 1918, but would matter again in the future: "So Karl Marx's intellectual work can be a measure for the greatness of the working class at a later time “11 (Vorwärts 1918, 2). It becomes evident how class struggle and socialism formed a mere lip service for revisionist social democrats.

At the time of the split of the Party into a pro- and an anti-First World War faction in 1915, Rudolf Hilferding was the newspaper's chief-editor and Vorwärts supported the anti-war position. But Hilferding was replaced by Friedrich Stampfer as chief-editor in 1916 so that the newspaper at the time of Marx's centenary represented the Party's mainstream positions of Friederich Ebert and Philipp Scheidemann. Scheidemann was Chancellor of the Weimar Republic when right-wing paramilitaries under Waldemar Pabst murdered Rosa Luxemburg and Karl Liebknecht in 1919, which was tolerated by Scheidemann's Minister of Defence Gustav Noske.

\section{How the News Media Reported on Marx's Centenary}

In London, where Marx lived from 1849 until his death in 1883, socialists planned a celebration of his centenary in Finsbury Park. An advertisement printed in the Daily Herald on 4 May (see Figure 1) makes clear that eight trade councils and over one hundred trade union branches and co-operatives supported the event that was planned to take place in Finsbury Park on 5 May. It should have featured speakers on eight platforms. The Herald also printed the resolution that the organisers (The North London Labour Demonstration Committee) planned to read out on all eight platforms:

This mass meeting of London workers, on the centenary of the birth of Karl Marx, recalls with gratitude his devoted labours on behalf of the cause of International Socialism. Having no quarrel with the workers of any country, it extends fraternal greetings to them all, paying particular tribute to those Russian comrades who have waged such a magnificent struggle for their Social and Political emancipation. It emphatically protests against the continuation of the present Capitalistic war, and urges the workers of all lands immediately to meet in conference and arrange a "Peoples' Peace" on the basis of "no annexations and no indemnities". It further vigorously protests against the continued imprisonment of those holding a conscientious objection to military service, and demands their immediate and unconditional release. It demands full political and civil rights for all workers, including soldiers, sailors, and civil servants. Finally, it reaffirms its belief in the solidarity of the workers of all lands, in the cause of International Brotherhood and goodwill amongst all peoples. Workers of London rally behind your Banners! Demonstrate your belief in the Solidarity of the Working Class the World over - of Internationalism, Brotherhood and Goodwill amongst all Peoples. Rally! Rally!! Rally!!!" (Daily Herald, May 4 1918, 11).

The Home Secretary prohibited the public event. In the USA, the New York Herald reported that in London, the "celebration of the centenary of the birthday of Karl Marx,

10 „In Deutschland muß sich die Marxfeier auf Würdigungen des Meisters in der Presse und auf Festlichkeiten in geschlossenem Kreise beschränken".

${ }^{11}$ „So kann das geistige Werk von Karl Marx ein Maßstab sein für die Größe der Arbeiterklasse einer späteren Zeit“. 
the German Socialist, arranged to be held in a London park tomorrow, has been prohibited by the Home Secretary on the ground that it would be likely to cause disorder and make undue demands on the police. The principal organiser of the meeting was a pacifist weekly paper and several trade unions cooperated. There were to have been bands and banners and speeches, with resolutions against a 'capitalistic war'" (Marx Celebration Halted, New York Herald, 5 May 1918, 2).

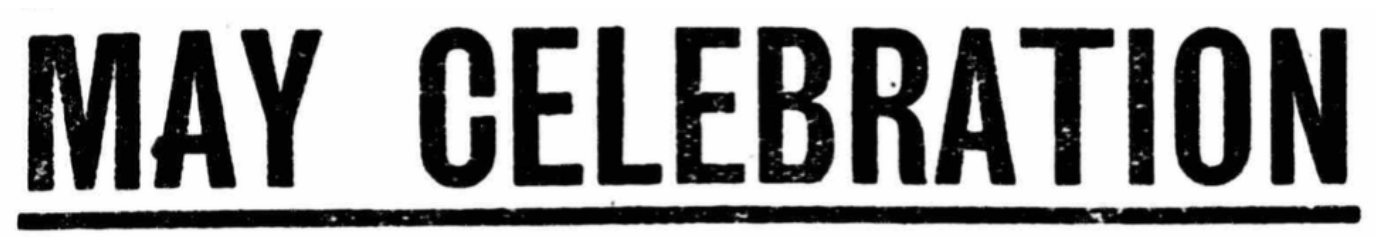

\section{GREAT RANK \& FILE LABOUR DEMONSTRATION}

IN

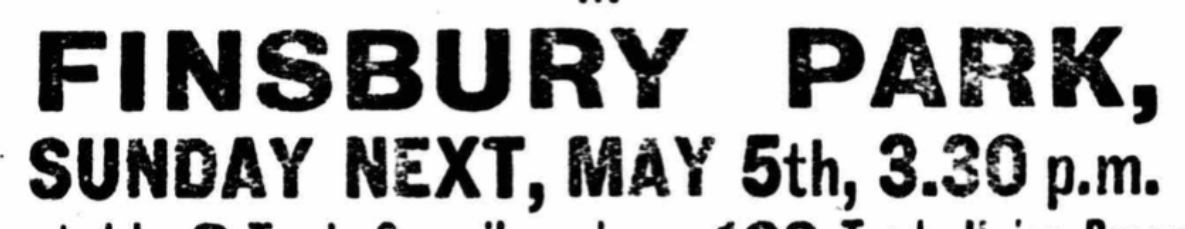

Supported by 8 Trade Councils and over 100 Trade linion Branches, Co-operative Societies, \&c.
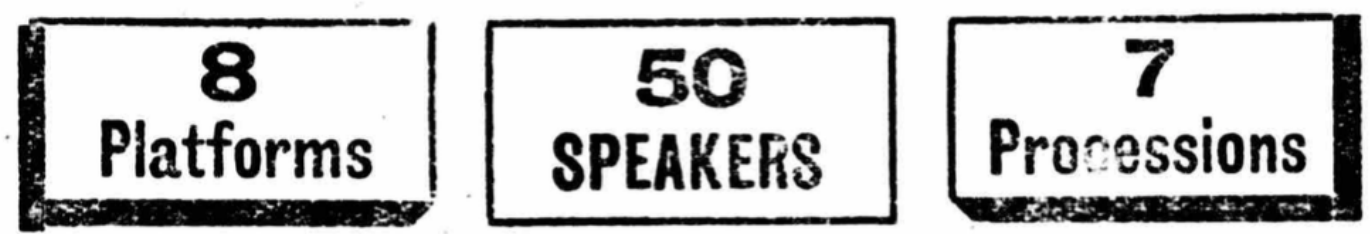

WELL-KNOWN SPEAKERS IN THE TRADE UKION AND POLUTICAL HORLD

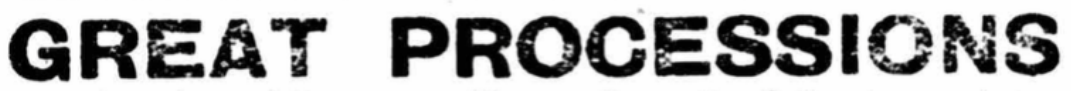
with Ba: ds and Banners will start from the following points:

Edmonton Town Kall, 1.39 p.m.

Camden Town N. L. Riy, Stn., 2.15 p.m.

Hackney Town Kall, 1.30 p.m.

Highgate Archway Tavein, 2.30 p.m.

tiolloway Prison, 2.45 p.m.

Tottenisam, Northiuti'seriaid Pk., 2 p.m.

Waithainstow, Stankard Corner, Black-

horse Road, 1.30 p.m.

Figure 1: Advertisement for a rally celebrating Marx's centenary in London's Finsbury

Park (data source: Daily Herald, May 4 1918)

In the USA, the New York Times on the same day ran an overall appreciative piece titled Today is 100th Anniversary of Marx's Birth: "Few men have more profoundly influenced the life and thought of their own and succeeding generations than the great author of 'Das Kapital,' upon whom the world has, with questionable accuracy, conferred the title 'Father of Modern Socialism'. [...] The great war seems destined to mark the close of the era of Marxism in Socialist history. [...] The centennial of Marx's birth may be regarded, at the same time, as the end of Marxian socialism" (Spargo 1918, 11-12). 
The Globe was a London-based newspaper owned by William Maxwell Aitken, who at that time was Britain's Minister of Information in David Lloyd George's government. It is of course interesting but not surprising that the Minister of Information at that time was a media baron who controlled the Daily Express and The Globe. At the same time, Alfred Harmsworth, who owned the the Daily Mirror and The Times and had founded the Daily Mail (that at that time was owned by his brother Harold Harmsworth), was the British government's Director of Propaganda. Putting the owners of large newspapers in control of propaganda and information policies constitutes a direct state-capitalnexus that undermines the freedom of the press and makes sure that there is progovernment reporting. In this particular case, the political appointments served the purpose of war propaganda and the opposition to socialism and pacifism.

This circumstance becomes evident in a piece printed in Aitken's The Globe on 2 May 1918, under the title "Pacifists Seek Trouble" that reported there is "every indication" that in respect to the planned "Pacifists' demonstration [...] arranged to be held in Finsbury Park [...] the British public will take the matter in their own hands and give the demonstrators a short shrift [...] unless the authorities step in and prohibit the meeting" (The Globe, 2 May 1918,3). So the newspaper called on the state to prohibit the Marx meeting and on anti-socialists to violently disrupt it. Tellingly, next to this report The Globe featured a large call with the title "HELP to advance the British Financial Front" that calls the readers to buy National War Bonds. "YOUR COUNTRY needs $£ 25,000,000$ every week from the sale of National War Bonds. The money must be found. Are you doing your utmost to help? [...] Find out where you can cut expenses, and lend your country the money saved. [...] You are personally responsible for some part of that $£ 25,000,000$. Rich or poor - man or woman - it is to you that our sailors and soldiers look to provide the means of victory. They have faith in you. Prove that your faith is well-founded. Give them your support" (The Globe, 2 May 1918, 3).

Also The Times that was owned by the UK-government's Director of Propaganda Alfred Harmsworth reported negatively on Marx's centenary. On 2 May, it reported The Times reported that "Labour's May Day will be next Sunday, the centenary of Karl Marx, when there will be a procession to Highgate Cemetery, and flowers will be placed on Marx's grave". The conservative newspaper titled this short news piece "May Day. Anti-Socialist Demonstrations at Glasgow" and wrote in it that the May Day demonstrations in Glasgow were "one of the largest of recent years", but that there were "a number of exciting incidents", including spectators shouting "go and join the Army" (The Times, 2 May 1918, 3). On May 1, The Times ran a short news item titled "Karl Marx Unhonoured" that reported that in France, a "proposal to celebrate the centenary of Karl Marx [born 5 May 1818] has been rejected by the executive committee of the Federation of the Seine".

The Chicago Daily Tribune reported about a celebratory event in Chicago, writing that an "admission charge of 35 cents and a wardrobe tip of 15 cents straight assured the exclusion of many and limited the attendance of the "Gigantic Karl Marx Celebration' to the 150 who had the price". The article spoke in its headline of the attendees as "elite Bolsheviki" and wrote that "every third tie was of crimson" (Chicago Daily Tribune, 6 May 1918, 3). To remind its readers of what should happen to socialists, the newspaper right next to this article printed one titled "Socialists Here Face Inquiry for Anti-War Stand".

The Scotsman reported on May 6 that the "peace demonstration, widely advertised as rank and file labour celebration of the centenary of Karl Marx [...] was prohibited by an order of the Home Secretary. Nevertheless, a crowd numbering between 500 and 
1000 people assembled at half-past three, and grouped themselves around improvised stands" (The Scotsman, 6 May 1918, p. 7).

In Germany, the liberal Berliner Volkszeitung published an article about Marx's centenary that criticised "the self-indulgent overestimation of this centenarian"12. "The number of owners has not just not continuously decreased, but has (thanks to the development of stockholding) steadily become larger. The 1,000-year Reich of the Proletarians is deferred to the distant future"13 (Fiedler 1918, 3). "For decades to come, the idea of the International, his favourite organisational plan, seems to be buried in the abyss that the World War has ripped up between the nations" 14 (Ibid.).

Overall, we can see from this incomplete review that the reactions to Marx's centenary ranged from taking his work and life as an inspiration for the struggles of the time on the one side of the spectrum to on the other side radical dismissals of Marx's works and politics that also featured calls for the use of violence to impede celebrations.

\section{Conclusion}

The cultural forms, in which Marx's centenary was reflected in 1918, included press articles, essays, speeches, rallies, demonstrations, music, and banners. One hundred years later, we can find besides all of these cultural forms of commemorating Marx's bicentenary also expressions of engagement, inspiration, interest and rejection that take on the form of memes, social media, documentaries, radio and television reports, movies, novels, exhibitions, souvenirs, books, collected volumes, etc. One should in this context not turn Marx into a depoliticised cultural spectacle (Marx for Marx's sake), but rather take the opportunity to treat him as undead and as capitalism's walking dead, who reminds us of the necessity to critically theorise and politically criticise capitalism and to struggle for alternatives (Marx for the sake of a commons-oriented society). We need to repeat Marx today.

\section{References}

Adler, Max. 1918. Die sozialistische Idee der Befreiung bei Karl Marx. Zu seinem hundertsten Geburtstage am 5. Mai 1918. In Max Adler: Ausgewählte Schriften, ed. Norbert Leser and Alfred Pfabigan, 478-489. Vienna: Österreichischer Bundesverlag.

Arbeiter-Zeitung. 1918. Karl Marx. 5 May: 1-3.

Debs, Eugene, V. 1918. Karl Marx the Man: An Appreciation. St. Louis Labor 900 (May 4, 1918): 1.

Die Neue Zeit. 1918. Karl Marx. 3 May 1918. 36: 97-103.

Fiedler, Alfred. 1918. Das tausendjährige Reich. Zum 100. Geburtstag von Karl Marx (5. Mai). Berliner Volkszeitung, 5 May 2018: 3.

Fitzgerald, Jack. 1918. The Centenary of Marx. Socialist Standard, May 1918. https://www.marxists.org/archive/fitzgerald/marxcentenary.htm

Gramsci, Antonio. 1918. Our Marx. In The Gramsci Reader: Selected Writings, 1916-1935, ed. David Forgacs, 36-40. New York: NYU Press.

Hardt, Michael and Antonio Negri. 2017. Assembly. Oxford: Oxford University Press.

12 „die maßlose Überschätzung dieses Hundertjährigen“

13 "Die Zahl der Besitzenden ist nicht nur nicht beständig kleiner, sondern sogar (dank der Entwicklung des Aktienwesens) beständig größer geworden. Das tausendjährige Reich des Proletariats rückt in weite, ungreifbare Ferne"

14 „Auf Jahrzehnte hinaus scheint der Gedanke der Internationale, sein organisatorischer Lieblingsplan, in der Kluft versunken zu sein, die der Weltkrieg zwischen den Völkern aufgerissen hat". 
Goethe, Johann Wolfgang von. 1914. West-Eastern Divan. London: Dent \& Sons.

Kautsky, Karl. 1918. Marx über Realpolitik. Arbeiterwille: Organ des arbeitenden Volkes für Steiermark und Kärnten, 5 May 1918: 1-3.

Left Communists. 1918. The Left Communists' Theses on the Current Situation. https://libcom.org/library/theses-left-communists-russia-1918

Lenin, Vladimir I. 1918. "Left-Wing" Childishness and the Petty-Bourgeois Mentality. In Lenin Collected Works Volume 27, 323-354. Moscow: Progress.

Luxemburg, Rosa. 2011. The Letters of Rosa Luxemburg, ed. Georg Adler, Peter Hudis and Annelies Laschitza. London: Verso.

Luxemburg, Rosa. 1916. The Junius Pamphlet: The Crisis in the German Social Democracy. In Rosa Luxemburg Speaks, 371-477. New York: Pathfinder.

Marx, Karl. 1857/58. Grundrisse. London: Penguin.

Marx, Karl and Friedrich Engels. 1845/46. The German Ideology. In Marx \& Engels Collected Works (MECW) Volume 5, 19-539, London: Lawrence \& Wishart.

Mehring, Franz. 2003/1936. Karl Marx: The Story of His Life. Abingdon: Routledge.

Mehring, Franz. 1918. Karl Marx. In Franz Mehring Gesammelte Schriften Band 4: Aufsätze zur Geschichte der Arbeiterbewegung, 11-15. Berlin: Dietz.

Schumpeter, Joseph. 1918. Karl Marx, der Denker. Arbeiterwille: Organ des arbeitenden Volkes für Steiermark und Kärnten, 5 May 1918: 3.

Spargo, John. 1918. Today is 100th Anniversary of Marx's Birth. New York Times, 5 May 1918, 11-12.

Vorwärts. 1918. Zum 100. Geburtstag von Karl Marx. 5 May 2018: 1-2.

\section{About the Author}

Christian Fuchs

Christian Fuchs is a critical theorist of communication and society. He is co-editor of the journal tripleC: Communication, Capitalism \& Critique and a professor at the University of Westminster.@fuchschristian http://fuchs.uti.at 